INTERNATIONAL JOURNAL OF CURRENT RESEARCH IN CHEMISTRY AND PHARMACEUTICAL SCIENCES

(p-ISSN: 2348-5213: e-ISSN: 2348-5221)

www.ijcrcps.com

DOI: 10.22192/ijercps

Coden: IJCROO(USA)

Volume 7, Issue 12 - 2020

Research Article

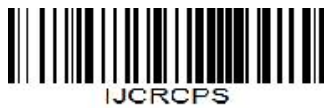

DOI: http://dx.doi.org/10.22192/ijcrcps.2020.07.12.003

\title{
The Effects of Green Apple Juice (Pyrus malus L.) on Cholesterol Levels in Guinea Pig (Cavia cobaya)
}

\author{
Fahma Shufyani ${ }^{1}$, Jhon Patar Sinurat ${ }^{2}$, Rinaldo Berutu ${ }^{3}$ \\ ${ }^{1,3}$ Department of Pharmacy, Faculty of Pharmacy, Institut Kesehatan Medistra Lubuk Pakam, \\ Sudirman Street No. 38 Lubuk Pakam, Kab. Deli Serdang, Sumatera Utara \\ ${ }^{2}$ Department of Medical Laboratory Techology, Faculty of Pharmacy, Institut Kesehatan Medistra Lubuk \\ Pakam, Sudirman Street No. 38 Lubuk Pakam, Kab. Deli Serdang, Sumatera Utara
}

E-mail*: fahmaapotekerunand@yahoo.com

\begin{abstract}
The chemical compound content of green apple juice was pactin, which wass a group of polysaccharides that can lower cholesterol levels. In addition, there were also several secondary metabolites, including flavonoids, glycosides and triterpenoids. To determine the effect of giving green apple juice on the blood cholesterol levels of guinea pigs treated with hypercholesterolemia by giving food mixed with 15\% European chicken egg yolk, 15\% goat fat, 20 grams of feed for 6 days. The study was divided into 5 groups (A, a, b, c and S) measured cholesterol levels, group A was given aquadest orally (negative control), groups a, b, c were given green apple juice orally at a dose of 2.03 grams / kg BW, dose 4.06 gram / kg BW, 6.09 gram / kg BW, group S was given $0.01 \%$ simvastatin suspension at a dose of $0.775 \mathrm{mg} /$ $\mathrm{kg} \mathrm{BW}$ orally as a positive control for 14 days. Based on the results of the research tested using statistics, it was obtained that the administration of green apple juice at a dose of 2.03 grams / kg BW, a dose of 4.06 grams / kg BW, a dose of 6.09 grams / $\mathrm{kg} \mathrm{BW}$ showed that the reduction in cholesterol levels was not significantly different from giving simvastatin 0 suspension. $01 \%$ dose $0.775 \mathrm{mg} / \mathrm{kg} \mathrm{BW} /$ day.
\end{abstract}

Keywords: Green Apple Juice, Cholesterol, Guinea Pig, Simvastatin

\section{Introduction}

Changes in diet in people who like fast food cause various health problems. The wrong lifestyle and bad habits that become daily routines will result in increased levels of cholesterol in the blood. (Dan \& Triton, 2017)

Hypercholesterolemia is a condition characterized by increasing levels of total cholesterol and Low

(C) 2020, IJCRCPS. All Rights Reserved
Density Lipoprotein (LDL) and decreasing blood High Density Lipoprotein (HDL). (Azhari et al., 2017)

Therapy that is often done to reduce cholesterol levels is to provide synthetic drugs such as the statin class. However, the weakness of the statins have side effects of myopathy and rhabdomyolysis. (Azhari et al., 2017) 
Cholesterol is a substance that is produced by the body about $80 \%$, therefore cholesterol cannot be treated, but must be lowered to normal limits. One way to lower cholesterol in the blood is by consuming green apples. Green apples are easy to find and affordable (Septianggi et al., 2013)

Green apples contain pectin which is a watersoluble polysaccharide compound. The content of pectin can act as anti-cholesterol properties, besides that, if pectin interacts with vitamin $\mathrm{C}$ it can also lower blood cholesterol. (Nurman \& Sastri, 2017)

Based on the above, the researchers are interested in using green apple as lowering cholesterol in guinea pigs who had previously been in a state of hypercholesterolemia by administering egg yolks Europe $15 \%$ and $15 \%$ fat goat with a comparator simvastatin tablets in the market.

\section{Methods}

\section{Equipments and Materials}

The equipments are spectrophotometric microlab 300, waterbath, nail cutter, micropipette and centrifuge.

Materials are green apples, guinea pigs, 96\% ethanol, simvastatin suspension preparation and distilled water.

\section{Preparation of Animals}

The animals used in this study were 30 healthy local breed guinea pigs (Cavia cobaya) obtained from the Berastagi area with a body weight of 300-500 grams, first conditioned for 2 weeks to adjust to their environment, then their initial cholesterol levels were measured. (Wijayanti et al., 2016)

\section{Hypercholesterolemia}

The guinea pigs were first measured for their initial cholesterol levels, then given regular feed (BR 1 281) with European chicken egg yolk and goat fat with various concentrations of 5\%: $5 \%$,

(C) 2020, IJCRCPS. All Rights Reserved
10\%: 10\%, 15\%: 15\%, 20\%.: $20 \%, 1 \%: 5 \%, 1 \%$ : $10 \%, 1 \%: 15 \%, 1 \%: 20 \%$ of the amount of food / day that is 20 grams for 7 days. After that the blood cholesterol levels were measured.

The guinea pig cholesterol levels were measured initially, then hypercholesterolemia was made by giving $15 \%$ European chicken egg yolk inducer food and $15 \% \mathrm{BW}$ of goat fat from the amount of food per day, namely 20 grams for 7 consecutive days orally. Measured blood serum cholesterol levels. (Ahidin et al., 2019) (Chahyanto et al., 2017)

\section{Simvastatin and aquadest}

The method used in this study was 5 types of treatment, namely treatment $\mathrm{A}, \mathrm{a}, \mathrm{b}, \mathrm{c}$ and $\mathrm{S}$ to determine blood serum cholesterol levels of guinea pigs. Only 1 group of hypercholesterolemic guinea pigs was given $0.01 \%$ Simvastatin suspension, namely the $\mathrm{S}$ group. Simvastatin suspension was given for 14 days. Blood serum cholesterol levels were checked after given of Simvastatin suspension on day 7 and day 14. Then for group A, they were given aquadest. (Ahidin et al., 2019) (Yuliyanti et al., 2019)

\section{Green Apple Fruit Juice}

Only 3 groups of hypercholesterolemic guinea pigs were given green apple juice, namely group a was given green apples at a dose of $2.03 \mathrm{~g} / 350 \mathrm{~g}$ $\mathrm{BW}$ of guinea pigs, group $\mathrm{b}$ was given green apples at a dose of $4.06 \mathrm{~g} / 350 \mathrm{~g}$ BW of guinea pigs, group c were given green apples at a dose of $6.09 \mathrm{~g} / 350 \mathrm{~g} \mathrm{BW}$ of guinea pigs given orally. The guinea pig blood serum cholesterol levels were measured after giving green apples on the 7th and 14th day. (Yuliyanti et al., 2019)

\section{Blood sampling}

The guinea pigs are fasted for 10-12 hours, then the fur of the guinea pigs are cut. The nails are cleaned with a wet toothbrush to remove sand and other impurities, then the guinea pig's feet and nails are cleaned with $70 \%$ alcohol. After that, the guinea pig's nails are cut with a nail clipper until it 
bleeds, then the dripping blood is collected in a 1 $\mathrm{ml}$ tube of clean serum. Blood draws are carried out at an interval of 7 days for 21 days and each animal blood draw is fasted first (Yuliyanti et al., 2019) (Vol, 2018)

\section{Cholesterol level measurement}

The blood is centrifuged for 10 minutes with speed of $1000 \mathrm{rpm}$, it will produce 2 layers, namely the serum and solids. Pipette the serum as $10 \mu 1$, then put into a tube containing $1000 \mu 1$ cholesterol reagent. Homogenized and incubated in a water bath for 10 minutes at $37^{\circ} \mathrm{C}$. Blood serum cholesterol values were measured using the CHOD-PAD colorimetric method with a Microlab 300 Spectrophotometric instrument with a wavelength of $546 \mathrm{~nm}$. (Asetat-edta, 1998)

\section{Data processing}

The data were analyzed using ANOVA (analysis of variance) and continued with Duncan's average difference test using version 15 of the SPSS (Statistical Product and Service Solution) (Yuliyanti et al., 2019)

\section{Results and Discussion}

Testing of the antihypercholesterolemic effect of green apples juice was carried out on guinea pigs weighing 300-500 grams which were hypercholesterolemic by giving inducers in various variations in the ratio of a mixture of European chicken egg yolk (\%) and goat fat (\%), among others. : (5: 5), (10:10), (15:15), (20:20), (1: 5), (1:10), (1:15), (1:20) for 7 consecutive days showed an increase in normal blood cholesterol levels to hypercholesterolemia. The results of changes in mean blood fat in guinea pigs after giving the inducer with various ratios (\%) can be seen in Table 1 and Figure 1 below:

Table 1. Changes in the average guinea pig blood serum cholesterol levels after a given treatment

\begin{tabular}{|c|c|c|c|}
\hline $\begin{array}{c}\text { The concentration of } \\
\text { European chicken egg } \\
\text { yolk and goat fat (\%) } \\
\text { with a feed of 20 grams / } \\
\text { day }\end{array}$ & \multicolumn{3}{|c|}{$\begin{array}{c}\text { Blood serum cholesterol levels (mg / dl) of } \\
\text { guinea pigs after giving oral European chicken } \\
\text { egg yolk and goat fat }\end{array}$} \\
\cline { 2 - 4 } & Normal & P1 & P2 \\
\hline $5: 5$ & 40 & 59,5 & 98,9 \\
\hline $10: 10$ & 37 & 68,3 & 117,7 \\
\hline $15: 15$ & 38,5 & 81,2 & 124,6 \\
\hline $20: 20$ & 38 & 127 & 229,1 \\
\hline $1: 5$ & 43 & 52,3 & 85,2 \\
\hline $1: 10$ & 38 & 86,8 & 150 \\
\hline $1: 15$ & 41 & 96,5 & 177,7 \\
\hline $1: 20$ & 43 & 116,6 & 202,6 \\
\hline
\end{tabular}

Description :

Normal: Checks normal cholesterol levels.

P I : Checking cholesterol levels after giving European chicken egg yolk and goat fat for 3 days.

P II : Checking cholesterol levels after giving European chicken egg yolks

and goat fat for 7 days. 
Int. J. Curr. Res. Chem. Pharm. Sci. (2020). 7(12): 18-23

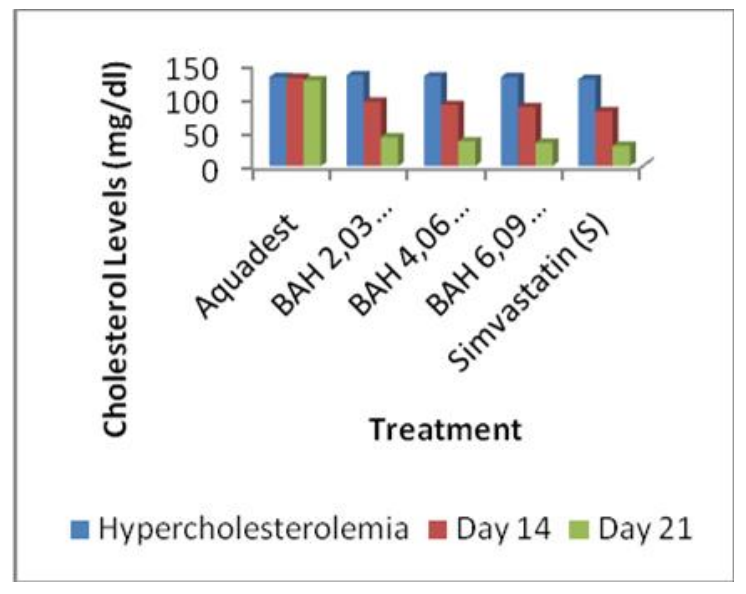

Figure 1.Graph of the average percentage reduction in guinea pig blood serum cholesterol levels after giving aquadest, green apples (BAH) at a dose of $2.03 \mathrm{~g} / 350 \mathrm{~g} \mathrm{BW}$ of guinea pigs, green apples (BAH) at a dose of $4.06 \mathrm{~g} / 350 \mathrm{~g} \mathrm{BW}$ of guinea pigs, green apples (BAH) at a dose of $6.09 \mathrm{~g} / 350 \mathrm{~g}$ BW guinea pig, and $0.01 \%$ simvastatin suspension at a dose of $3.1 \mathrm{ml} / 400 \mathrm{~g} \mathrm{BW}$

Description :

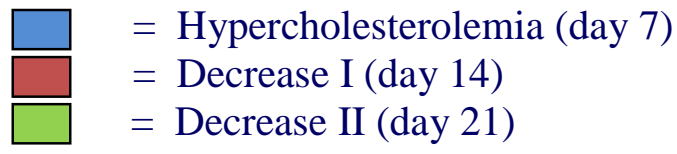

The level of cholesterol is done by checking levels of blood serum taken after fasting (not eating) for 10-12 hours so that the results are not affected by the food eaten. During fasting only water is allowed.

Blood sampling was done by cutting the guinea pig's toenails until it bled, then collected in a serum tube and measured using a Spectrophotometric Microlab 300 device. This method was chosen because of its simple, fast and precise implementation. Spectrophotometric is used to read the absorption of serum and blank solutions at a wavelength of $546 \mathrm{~nm}$.

Measurement of blood serum cholesterol levels for guinea pigs was carried out at the Regional Health Laboratory Center, Medan, North Sumatra.

For positive control of green apple fruit has softened simvastatin $10 \mathrm{mg}$ of the drug used, the selection of these drugs, because they are economical. The effect of simvastatin as cholesterol-lowering has been seen within 2 weeks and a maximum after 1 month of use.
The results of the ANOVA test on day 0 and day 7 showed no significant difference between test groups ( $p>0.05$ ), while on day 14 and day 21 there was a significant difference between test groups. ( $\mathrm{p}<0.05$ ). To find out a meaningful difference.

According to Duncan's mean difference test on day 14, it was obtained that the simvastatin suspension group was $0.01 \%$ at a dose of 3.1 $\mathrm{ml} / 400 \mathrm{~g} \mathrm{BW}$ in the subset. This showed that the administration of $0.01 \%$ simvastatin suspension with a dose of $3.1 \mathrm{ml} / 400 \mathrm{~g} \mathrm{BW}$ can reduce cholesterol levels which are not significant to the aquadest group, where the aquadest group of guinea pigs is still in a hypercholesterolemic condition, while the green apple group with a dose of $2.03 \mathrm{~g} / 350 \mathrm{~g} \mathrm{BW}$ guinea pigs, a dose of $4.06 \mathrm{~g} / 350 \mathrm{~g}$ BW of guinea pigs and a dose of $6.09 \mathrm{~g} / 350 \mathrm{~g}$ BW of guinea pigs compared to aquadest showed a difference, this means that green apples juice can reduce cholesterol levels significantly and statistically. 
According to Duncan's average difference on day 21 , it was found that giving green apples at a dose of $4.06 \mathrm{~g} / 350 \mathrm{~g} \mathrm{BW}$ of guinea pigs, a dose of $6.09 \mathrm{~g} / 350 \mathrm{~g} \mathrm{BW}$ of guinea pigs and giving $0.01 \%$ simvastatin suspension with dose of $3.1 \mathrm{ml} / 400 \mathrm{~g}$ BW compared to the provision of green apples juice with dose of $2.03 \mathrm{~g} / 350 \mathrm{~g}$ BW guinea pig and aquadest showed a difference, this means that green apple juice and simvastatin suspension have activity to reduce cholesterol levels significantly. Meanwhile, giving green apples that had been at a dose of $4.06 \mathrm{~g} / 350 \mathrm{~g} \mathrm{BW}$ of guinea pigs and a dose of $6.09 \mathrm{~g} / 350 \mathrm{~g} \mathrm{BW}$ of guinea pigs showed a reduction in cholesterol levels was not statistically significant difference with the provision of $0.01 \%$ simvastatin suspension at a dose of $3.1 \mathrm{ml}$. / $400 \mathrm{~g}$ BW.

\section{Conclusion}

Green apples juice can reduce cholesterol levels. Pectin and secondary metabolites in green apples is claimed that reduce cholesterol levels.

From the results of statistical tests, it was found that giving green apples juices at a dose of 2.03 $\mathrm{g} / 350 \mathrm{~g} \mathrm{BW}, 4.06 \mathrm{~g} / 350 \mathrm{~g} \mathrm{BW}$ of guinea pigs showed significantly different reduction with $0.01 \%$ simvastatin suspension at a dose of 3.1 $\mathrm{ml} / 400 \mathrm{~g} \mathrm{BW}$, while $0.01 \%$ simvastatin suspension at a dose of $3.1 \mathrm{ml} / 400 \mathrm{~g} \mathrm{BW}$ showed a stronger reduction compared to giving green apples that had been set with dose of $6.09 / 350 \mathrm{~g}$ BW guinea pig.

\section{Acknowledgments}

The author highly appreciates the financial support from the Directorate of Research \& Community Service (DRPM), Ministry of Research, Technology and Higher Education of the Republic of Indonesia.

\section{References}

Ahidin, D., Firmansyah, D., \& Khairunisah, G. (2019). Effectiveness Ofethanol Extract Of Red Beans (Phaseolus vulgaris L.) On Reducing Total Cholesterol Conditions In White Mice (Mus musculus). Medical Sains: Junal Ilmiah Kefarmasian, 3(2), 67-74. https://doi.org/10.37874/ms.v3i2.72

Asetat-edta, E. D. T. A. E. T. (1998). LDL-C Qualitative And Quantitative Analysis Methods ( Rosi S ., Gelgel W., Junitha ).

Azhari, B., Luliana, S., \& Robiyanto. (2017). Antihypercholesterolemic Test of Wuluh Starfruit Water Extract (Averrhoa bilimbi Linn.) In Modeling Galung Wistar Male Mice Antihypercholesterolemia. Traditional Medicine Journal, 22(1), 57-62.

Chahyanto, B. A., Marliyati, S. A., \& Winarsih, W. (2017). Effects of a High Cholesterol Diet on Increased Blood Cholesterol, Liver Histopathology, and Body Weight of a New Zealand White Male Rabbit. Jurnal Sain Veteriner, 34(1), 50-59.

https://doi.org/10.22146/jsv.22814

Nurman, Z., \& Sastri, S. (2017). Research article The Effect of Apple Pectin (Malus Sylvestris Mill) on LDL Cholesterol Levels in Hypercholesterolemic Male White Rats (Rattus Novergicus). 3(3), 679-684.

Septianggi, F. N., Mulyati, T., \& K, H. S. (2013). Relationship of Fat Intake and Cholesterol Intake with Total Cholesterol Levels in Outpatient Coronary Heart Patients at Tugurejo Hospital. 2 (November), 13-20.

Vol, E. (2018). DOI: 10.24036/eksakta/vol19iss01/123. 19(1).

Wijayanti, D., Setiatin, E. T., Kurnianto, E., Diponegoro, U., Tembalang, K., \& Tengahindonesia, J. (2016). Effect of Binahong Leaf Extract (Anredera cordifolia (Ten) Steenis) on Red Blood Profile in Guinea Pig (Cavia cobaya). Effect of Binahong Leaf Extract (Anredera Cordifolia (Ten) Steenis) on Red Blood Profile in Guinea Pig (Cavia Cobaya), 34(1), 75-83.

https://doi.org/10.22146/jsv.22818 
Yuliyanti, Y., Tjandra, A. S. A., \& Setianingsih, H. (2019). The Effect Of Providing Apple (Malus sylvestris Mill) Variety Of Manalagi Variety On Blood Trygliceride Levels Of White Rat (Rattus Norvegicus) Male Wistar Line That Given With High Diet Of Fat And Indicated Aloksan. JURNAL AGRI-TEK: Jurnal Penelitian Ilmu-Ilmu Eksakta, 20(2), 70-75.

https://doi.org/10.33319/agtek.v20i2.28

\begin{tabular}{|c|c|}
\hline \multicolumn{2}{|c|}{ Access this Article in Online } \\
\hline \multirow{2}{*}{ 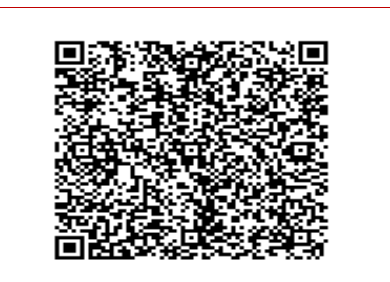 } & $\begin{array}{l}\text { Website: } \\
\text { www.ijcrcps.com }\end{array}$ \\
\hline & \multirow{2}{*}{$\begin{array}{l}\text { Subject: } \\
\text { Pharmaceutical } \\
\text { Sciences }\end{array}$} \\
\hline Quick Response Code & \\
\hline DOI: $10.22192 / \mathrm{ijcrc}$ & s.2020.07.12.003 \\
\hline
\end{tabular}

How to cite this article:

Fahma Shufyani, Jhon Patar Sinurat, Rinaldo Berutu. (2020). The Effects of Green Apple Juice (Pyrus malus L.) on Cholesterol Levels in Guinea Pig (Cavia cobaya). Int. J. Curr. Res. Chem. Pharm. Sci. 7(12): 18-23.

DOI: http://dx.doi.org/10.22192/ijcrcps.2020.07.12.003 